\title{
FACTORS AFFECTING THE MECHANICAL GRADING OF PEACH FRUITS
}

\author{
I. Yehia ${ }^{(1)}$, G. K. Arafa ${ }^{(2)}$, and A. Abd El Rasheed ${ }^{(3)}$
}

\section{ABSTRACT}

The main objective of the present study is to study factors affecting the mechanical grading of peach fruits. The studied parameters were: grading-drum speeds of 4, 7, 10 and $13 \mathrm{rpm}$ (0.05, 0.08, 0.12 and 0.15 $\mathrm{m} / \mathrm{s})$, fruit batch of $5,10,15$ and $20 \mathrm{~kg}$ and types of grading cylinder ( $P V C$ and rubber coated cylinder) using constant grading tilt angle of $7^{\circ}$. The main results in this study can be summarized in the following points: The maximum grading-efficiency of $98.9 \%$ were obtained with grading speed of $4-7 \mathrm{rpm}$ and feed rate of $5 \mathrm{~kg}$. Meanwhile, the minimum grading-efficiency of $83.6 \%$ were obtained with grading speed of 13 rpm., and feed rate of $20 \mathrm{~kg}$. The maximum fruit damage of $4.14 \%$ was obtained with grading speed of $13 \mathrm{rpm}\left(0.1^{\circ} \mathrm{m} / \mathrm{s}\right)$ fruit batch of $5 \mathrm{~kg}$ and PVC cylinder. Meanwhile, the minimum fruit-damage of zero and $0.07 \%$ was obtained with grading speed of $4 \mathrm{rpm}(0.05 \mathrm{~m} / \mathrm{s})$, fruit batch of $20 \mathrm{~kg}$ and rubber-coated cylinder. The maximum machine productivity of $1075.6 \mathrm{~kg} / \mathrm{h}$ was obtained with grading speed of $13 \mathrm{rpm}\left(0.1^{\circ} \mathrm{m} / \mathrm{s}\right)$ fruit batch of $20 \mathrm{~kg}$. Meanwhile, the minimum machine productivity of 295.9 $\mathrm{kg} / \mathrm{h}$ was obtained with grading speed of $4 \mathrm{rpm}(0.05 \mathrm{~m} / \mathrm{s})$, fruit batch of 5 $\mathrm{kg}$. The operation and production costs and rubber-coated cylinder) were 12.82 L.E./h and 26.98 L.E./ton at optimum conditions (grading speed of $7 \mathrm{rpm}$ or $0.08 \mathrm{~m} / \mathrm{s}$, fruit batch of $10 \mathrm{~kg}$ and rubber-coated cylinder.

\section{1- INTRODUCTION}

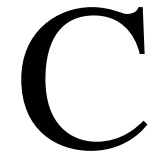

ultivated area of fruits in Egypt is 1.20 million fed. Peach is the major horticultural crops in Egypt. It is cultivation area is about $78.494 \mathrm{fed}$, and the total production of Peach in Egypt is about 224.183 ton, (Agric. Statistics Economic Affairs Sector, 2006). Peach considered from fruits with stone-fruits, as known, Amin (1994) developed and tested a grading machine consisting of rotating cylinder and perforated concave to grade potatoes crop.

(1) Prof.and Head of Mechanization systems of operatios,(2) and (3) Senior Res., and Res., Ag. Eng. Res. Inst., Respectively. 
The obtained results showed that crop parameters such as (tubers dimensions and mass) and machine parameters such as (cell area and shape, drum speed, slop of drum axle and drum length) have a significant effect on grading efficiency. The specifies of machine at drum speed of $25 \mathrm{rpm}$ and slop of zero degree was $1.2 \mathrm{Mg} / \mathrm{h}$ with tuber damage of 0.23 $\%$. El-Raie et al. (1998) designed and fabricated grading machine for orange using diverging bar and roller cylinder. The results showed that, the optimum speed of feeding conveyor was $70 \mathrm{rpm}$., the most suitable lines for the grading unit were the cylinders system, and the most suitable tilt angle of grading unit ranged between 0.052-0.105 rad. (3-6 degree).Mousa (1998) found that the mean values of diameter ranged from about 69 to $84 \mathrm{~mm}$; height ranged from about 57 to $87 \mathrm{~mm}$; mass ranged from about 160 to $208 \mathrm{~g}$; volume ranged from 188 to $241 \mathrm{~mm}$ for Navel, Baladi, Acidless and Valencia orange varieties. The height values limited the distance between grading lines and shape and size of the distributed buckets on the conveyor belt. According to that, the bucket design was: length of $650 \mathrm{~mm}$ and diameter of $100 \mathrm{~mm}$ more than the biggest height of orange fruits. Matouk et al. (1999) designed and constructed a portable chine for sorting, cleaning and grading sphere-like crops such as orange and tomatoes. They concluded that, at any sieve slop the range of 0.87-0.349 rad. (0-5 deg) and all sieve king speed in the range of 150-300 rpm mechanical damage percentage of fruits increased as the speed of fruits feeding chain increased from $0.15-0.3 \mathrm{~m} / \mathrm{s}$. They added that at high sieve rocking speed the grading efficiency of fruit decreased. Abd-Alla et al. (2000) reported that the grading efficiency was decreased with increasing both fruit feeding speed and tilt angle of grading unit. The grading efficiency was increased with the increase of critical distance to open the pivoted beam from 0.04-0.1 $\mathrm{m}$ and start to decrease at critical distance of $0.13 \mathrm{~m}$. Patrick (2002) mentioned that there are many methods of grading (grading system) were used: Lift roller seizer. The product is sized by lifting alternate rollers to vary the gap between rollers,screen grader. The product is sized by passing over a series of mesh screen.

Genidy (2003) stated that the machine grading capacity increased by 22.2 $\%$ when the cylinder speed of feeding was increased from 10-40 rpm 
$(0.11-0.42 \mathrm{~m} / \mathrm{s})$ at different levels of tilt angles during grading the muskmelon. Mostafa (2003) developed and fabricated an appropriate system for grading onion bulbs by size. He showed that, the optimum operational conditions at $0.23 \mathrm{~m} / \mathrm{s}$ and zero gerundial angles achieved maximum grading efficiency of $9 \%$ for giza 20 onion variety. Xiaoyang et al. (2003) developed a prototype automated pectin ayatem to classify apples based on bruising in real. The results show that the Raman spectroscope permits non-structive bruise determation with good results. The objective of this investigation is to study the factors affecting the mechanical grading of peach fresh-fruits such as grading speed, fruitbatch mass and grading cylinders material (PVC and rubber-coated).

\section{2- MATERIALS AND METHODS}

\section{2-1 Materials:}

\section{2-1-1 Fruits used in this investigation.}

Ripe fresh peach fruit "Hegazey" variety was used in this study. All measurements were done using a random sample of 100 fruits. The samples were taken randomly from peach trees (special farm in El Sharkia Governorate at acceptable harvesting date) and from "El Oboor" Market; the fruits were cleaned to remove all foreign matter such as dust, dirt, immature and damaged fruits and the measurements were taken in the same day.

\section{2-1-2 Grading machine specifications (designed by El-Raie et al., 2012).}

Overall length, width, and height of grading machine are 860, 960, and $1070 \mathrm{~mm}$, respectively. The grading machine consists of the following parts (fig. 1).

(a) Fruit box: made of wood sheet with thickness of $6 \mathrm{~mm}$, top dimensions of $350 \times 330 \mathrm{~mm}$ and bottom dimensions of $350 \times 80 \mathrm{~mm}$. The rear side of hopper has the angle with horizontal plane of 60 degree.

(b) Fruit bin: made of wood sheet with thickness of $24 \mathrm{~mm}$ and dimensions of $800 \times 525 \times 270 \mathrm{~mm}$. The fruit box was supported with 
rear side of fruit bin by two bolts. The rear side of the fruit bin is inclined with horizontal plane by $7^{0}$.

(c) Frame: made of iron angles with dimensions of $30 \times 30 \times 3 \mathrm{~mm}$. The frame has length of $760 \mathrm{~mm}$, width of $660 \mathrm{~mm}$ and rear height of 550 $\mathrm{mm}$ and front height of $460 \mathrm{~mm}$. The frame is inclined to front direction (grading-direction) by $7^{0}$.

(d) Grading revolving-drums: three revolving drums were made of PVC with diameter of $200 \mathrm{~mm}$ and length of $430 \mathrm{~mm}$, thickness of $4 \mathrm{~mm}$ and spacing $6 \mathrm{~mm}$. The three grading-drums have holes diameter of 35,40 and $45 \mathrm{~mm}$ and number of holes of 111, 104 and 77 respectively. Iron metal-sheet of $35 \mathrm{~mm}$ length, $32 \mathrm{~mm}$ width and 1.5 $\mathrm{mm}$ thickness was assembled upper grading-drums spacing and bolted on two sides of fruit bin.

(e) Fruit cutoff and chute: was made of PVC sheet with length of 450 $\mathrm{mm}$ and width of $160 \mathrm{~mm}$. Three fruit cutoffs were passed inside the three grading drums and were hinged with left side of frame by cantilevers. The fruits roll on the concaved part of cutoff (chute) and drop into funnels. The curved part prevents the jamming of fruits. The total inclined-angle of cutoff and chute is $11.5^{\circ}$.

(f) Power transmission: An electrical motor with power of $0.225 \mathrm{~kW}$ $(0.3 \mathrm{hp})$ is used to operate grading machine. Chains and sprockets were used to transmit the available power from the motor driven shaft to each cylinder in grading units.

\section{2-1-3 Instruments:}

(a) Digital caliper with vernier: with accuracy of $0.01 \mathrm{~mm}$, to measure different dimensions of peach fruits.

(b) Digital balance: with accuracy of $0.2 \mathrm{~g}$, to measure mass of peach fruits.

(c) Graduated cylinder: of $1000 \mathrm{~mL}$ with accuracy of $25 \mathrm{~mL}$ to determine the real density and volume of fruit by immersion in water.

(d) Friction and rolling-angle measuring device: An inclined plane was used to measure friction and rolling angles. 


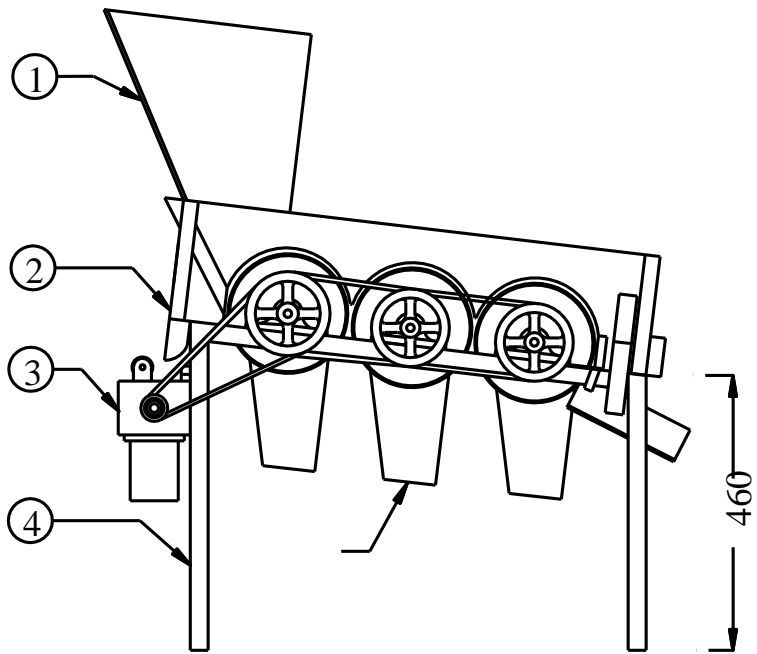

Elevation
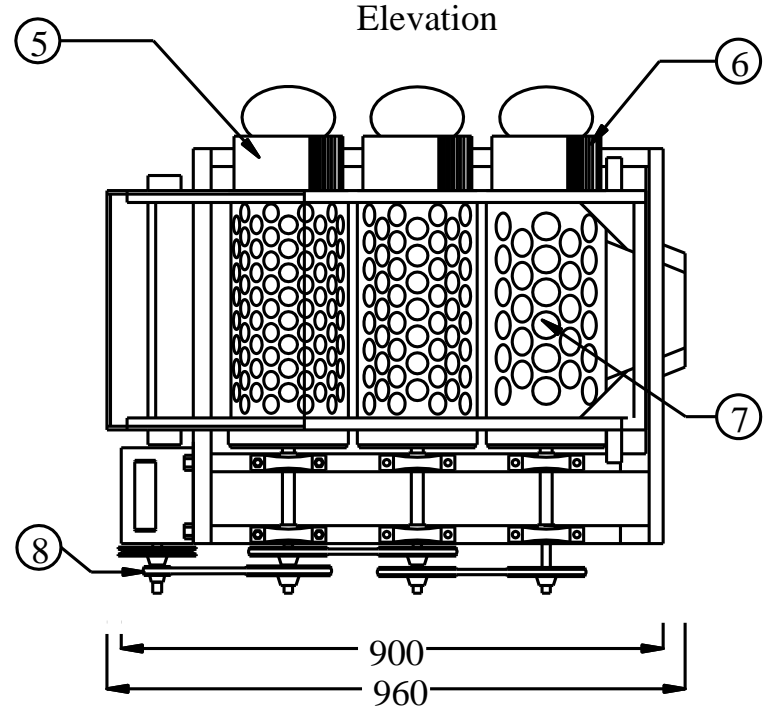

Plan

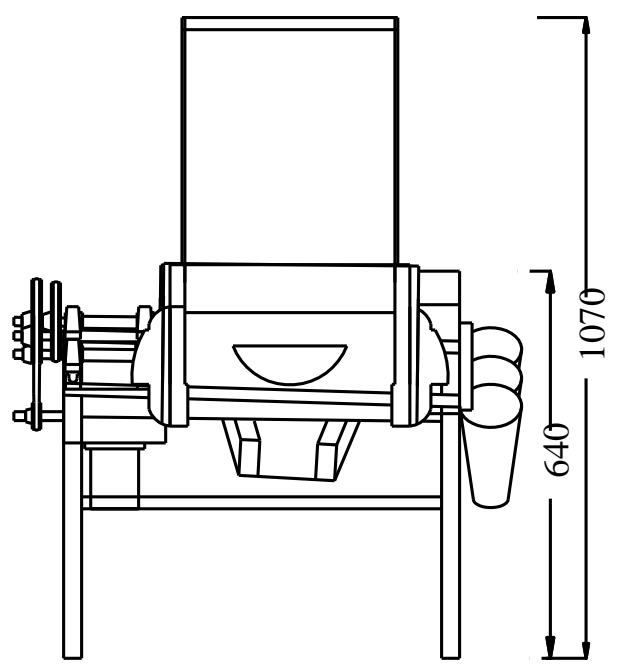

S.V.

1- Fruit hopper (box).

2- Frame.

3- Motor.

4- Stand.

5- Chute.

6- Cutoff.

7- Revolving drum.

8- Transmutation system.

Dims. in mm.

Fig. 1: Views of designed grading-machine for lemon fruits.

(e) Friction angle measurement: the fruits are placed as a group bounded together on a horizontal surface then the angle of inclination is gradually increased until the fruits begin sliding without rolling. For 
each fruits group of an average sample of (10), the friction angles were determined.

(f) Rolling angle measurement: the fruits are placed on a horizontal surface one by one then the angle of inclination is gradually increased until the fruits begin roll. For each fruit of an average sample (50), two angles of rolling are determined: for the maximum stable (with their base down) and minimum stable positions.

\section{2-2 Methods:}

\section{2-2 1-The studied variables:}

The following variables were tested to show their effect on grading efficiency, fruit damage and productivity:

1- Grading speed: Four different grading speeds of 4, 7, 10 and 13 $\mathrm{rpm}(0.05,0.08,0.12$ and $0.15 \mathrm{~m} / \mathrm{s})$,

2- Fruit batch: Four different feed rates of 5, 10, 15 and $20 \mathrm{~kg}$.

3- Grading-cylinders material: Two different types of PVC and rubber coated.

\section{2-2-2 Physical properties of the peach fruits:}

A random sample of one hundred fruits was taken from peach fruit (Hegazey variety) to measure physical properties.

The shape of peach fruit (Hegazey variety) was studied in terms of fruit height $(\mathrm{H})$ and diameter (D) in $\mathrm{mm}$. The digital caliper was used to measure different principal dimensions of fruit. Fruit shape index was taken as mentioned by Buyanov and Voronyuk, (1985). The following equations were used to calculate sphericity, projected area and real density according to Mohsenin, (1986) as follows:

(a) Sphericity ratio $=$ fruit height $(\mathrm{H}) /$ fruit diameter (D)

(b) Projected area $=4 / \pi(D * H)$

(c) Real density = Mass / Volume

\section{2-2-3 Mechanical properties of the peach fruits:}

(a) Rolling-angle measurement: The fruits are placed on a horizontal surface one by one then the angle of inclination is gradually increased until the fruits begin to roll. For each fruit of an average sample (50), the angle was determined for the maximum stable.

(b) Friction-angle measurement: The fruits are placed as a group bounded together on a horizontal surface then the angle of inclination 
is gradually increased until the fruits begin sliding without rolling. For each fruits group of an average sample (10), the friction angles were determined.

\section{2-2-4 Machine performances:}

(a) Grading productivity: It was calculated by using the following formula according to Amin (1994):

$$
\mathrm{P}=\frac{3600 * M}{T}
$$

Where: $\mathrm{P}=$ Grading productivity, $\mathrm{kg} / \mathrm{h} . \mathrm{M}=$ Mass of sample, $\mathrm{kg}$ and

$\mathrm{T}=$ Time in seconds.

(b) Grading efficiency: The grading efficiency $(\boldsymbol{\mu})$ of each outlet has been calculated according to El-Raie et al. (2012) as follows:

$\eta_{1}=\mathrm{M}_{\mathrm{o} 1} / \mathrm{M}_{\mathrm{i} 1}, \eta_{2}=\mathrm{M}_{\mathrm{o} 1} / \mathrm{M}_{\mathrm{i} 1}, \eta_{3}=\mathrm{M}_{\mathrm{o} 1} / \mathrm{M}_{\mathrm{i} 1}$, and $\eta_{4}=\mathrm{M}_{\mathrm{o} 1} / \mathrm{M}_{\mathrm{i} 1}$

Where: $\eta_{1}, \eta_{2}, \eta_{3}$ and $\eta_{4}$ : Grading efficiency of fruits for each outlet in the machine, $\%$.

$\mathrm{M}_{\mathrm{i} 1}, \mathrm{M}_{\mathrm{i} 2}, \mathrm{M}_{\mathrm{i} 3}$ and $\mathrm{M}_{\mathrm{i} 4}$ : Mass of each class inside fruit hopper, $\mathrm{kg}$ and $\mathrm{M}_{\mathrm{o} 1}, \mathrm{M}_{\mathrm{o} 2}, \mathrm{M}_{\mathrm{o} 3}$ and $\mathrm{M}_{\mathrm{o} 4}$ : Mass of the fruit for each outlet in the machine, $\mathrm{kg}$.

(c) Machine grading efficiency (Total grading efficiency): The total grading efficiency machine $(\boldsymbol{\eta})$ has been calculated using the following equation:

$\eta=\left(\eta_{1}+\eta_{2}+\eta_{3}+\eta_{4}\right) / 4$

(d) Mechanical damage: Percentage of mechanical damage was calculated by using the following formula:

$$
\mathrm{Df}=\frac{N d}{N t} \times 100
$$

Where: $\mathrm{N}_{\mathrm{d}}=$ Number of damaged fruits and $\mathrm{N}_{\mathrm{t}}=$ Total number of fruits.

(e) Estimating the costs of using the machine: The operation cost of washing machine was calculated according to the following equation given by Awady, 1978 modified for electrical motor drive:

$$
\mathrm{C}=\mathrm{P} / \mathrm{h}(1 / \mathrm{a}+\mathrm{I} / 2+\mathrm{t}+\mathrm{r})+(\mathrm{w} \cdot \mathrm{e})+\mathrm{m} / 144
$$

Where: $\mathrm{C}=$ hourly cost, $\mathrm{P}=$ price of machine, $\mathrm{h}=$ yearly working-hours, $\mathrm{a}=$ life expected of machine, $\mathrm{I}=$ interest rate/year, $\mathrm{t}=$ taxes and overhead ratio, $\mathrm{w}=$ power of motor in $\mathrm{kW}, \mathrm{e}=$ hourly $\operatorname{cost} / \mathrm{kW} . \mathrm{h}$, and $\mathrm{m} / 144=$ 
monthly wage ratio. Notice that all units have to be consistent to result in " $\mathrm{C}=\mathrm{LE} / \mathrm{h}$ ".

Operating cost $($ L.E./ton $)=$ machine cost $(\mathrm{LE} / \mathrm{h}) /$ machine productivity (ton/h)

\section{3- RESULTS AND DISCUSSION}

\section{3-1 Physical properties of peach fruit (Hegazey variety):}

Table 1 shows dimensions, sphericity, mass, volume and bulk density of peach fruits. These data were measured of 100 fruit sample, according to the standard set in (Mohsenin 1986).

Table 1: physical properties of peach fruit (Hegazey variety).

\begin{tabular}{|l|c|c|c|}
\hline Physical properties. & Max. & Min. & Average \\
\hline Diameter, mm. & 49.04 & 41.63 & 45.78 \\
\hline Height, $\mathrm{mm}$. & 46.82 & 40.55 & 43.72 \\
\hline Sphericity. & 0.95 & 0.97 & 0.96 \\
\hline Mass, g. & 51 & 42 & 46.5 \\
\hline Volume, $\mathrm{cm}^{3}$. & 50 & 32 & 40 \\
\hline Real density, $\mathrm{g} / \mathrm{cm}^{3}$. & 1.02 & 1.31 & 1.17 \\
\hline
\end{tabular}

(a) Dimensions of fruit.

Table 1 shows that the fruit diameter $(\mathrm{D})$ and height $(\mathrm{H})$ ranges of sample were 41.63 - $49.04 \mathrm{~mm}$ (average $45.78 \mathrm{~mm}$ ) and $40.55-46.82 \mathrm{~mm}$ (average $43.72 \mathrm{~mm}$ ) respectively. Fig. 2 indicates the percentage of frequency is $55 \%$ for peach fruits at mean fruits diameter of about $37 \mathrm{~mm}$ and mean fruits height of about $40 \mathrm{~mm}$ with the percentage of frequency $45 \%$.

\section{(b) Shape and size.}

If sphericiety is less than 0.9 , the fruit belongs to oblate group, if it is greater than 1.1 it belongs to oblong group, the remaining fruits with intermediate index values are considered to be round (Buyanov and Voronyuk, 1985). Table 1 indicates that the fruit sphericity ranged in sample between $0.95-0.97 \%$ (average $0.96 \%$ ) of peach fruit (Hegazey variety).

\section{(c) Mass, volume and bulk density.}

Table 1 indicates that the peach fruit (Hegazey variety) mass and volume ranges of sample were $42-51 \mathrm{~g}$, (average $46.5 \mathrm{~g}$ ) and $32-50 \mathrm{~cm}^{3}$ (average $40 \mathrm{~cm}^{3}$ ), respectively. Also, the fruit bulk density of sample were 1.02$1.31 \mathrm{~g} / \mathrm{cm}^{3}$ (average $1.17 \mathrm{~g} / \mathrm{cm}^{3}$ ). 


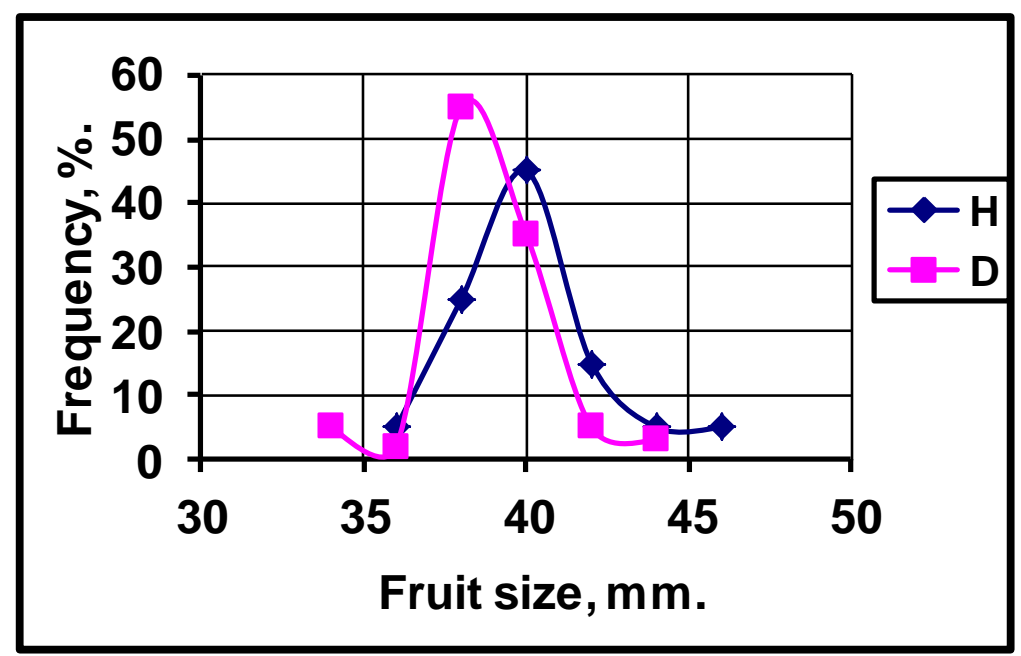

Fig. 2: Frequency curves distribution of fruit dimensions of peach fruit (Hegazey variety).

\section{3-2 Mechanical properties of the fruits.}

Table 2 shows friction and rolling angles of peach fruit (Hegazey variety). The maximum friction angle of 43 - 40 degree (average 41.5) and rolling angle of 38-25 degree (average 31.5 degree) were obtained with wood surface. Whereas, the minimum range of friction angle 20 - 18 degree (average 19 degree) and rolling angles 25 - 21 degree (average 23 degree) were obtained metal and stainless steal surface.

Table 2: Mechanical properties of peach fruit (Hegazey variety).

\begin{tabular}{|c|c|c|c|c|c|c|}
\hline \multirow{2}{*}{ Surface type } & \multicolumn{3}{|c|}{ Friction angle, } & \multicolumn{3}{c|}{$\begin{array}{c}\text { Rolling angle, } \\
\text { Degree }\end{array}$} \\
\cline { 2 - 7 } & Max. & Min & Av. & Max. & Min & Av. \\
\hline Wood & 43 & 40 & 41.5 & 38 & 25 & 31.5 \\
\hline Metal & 20 & 18 & 19 & 25 & 21 & 23 \\
\hline Stainless steal & 20 & 18 & 19 & 25 & 21 & 23 \\
\hline
\end{tabular}

\section{3-3 Effect of grading speed and feed rate on machine grading efficiency.}

Fig. 3 shows the effect of grading speed and feed rate on machine grading efficiency for PVC and rubber-coated cylinders. By increasing gradingspeed and fruit batch the grading efficiency decreased in general. There was a negative effect by increasing grading speed from 4 to $13 \mathrm{rpm}$ and increasing fruit batch from 5 to $20 \mathrm{~kg}$. 
The maximum grading-efficiency of $98.9 \%$ were obtained with grading speed of $4-7 \mathrm{rpm}$ and feed rate of $5 \mathrm{~kg}$. Meanwhile, the minimum grading-efficiency of $83.6 \%$ were obtained with grading speed of $13 \mathrm{rpm}$., and feed rate of $20 \mathrm{~kg}$.

The grading machine efficiency decreased by increasing grading speed is due do quick fruits passing over the grading revolving drums so decreasing the grading time of grading fruits. Meanwhile, the decreasing grading machine efficiency by increasing fruit batch is due to the fruits accumulated on the surface of drums.

Factors affecting grading efficiency were combined into prediction regression-equation under experiment and machine conditions as follows:

$$
\mathrm{n}=1.35 /\left(\mathrm{S}^{0.33} \cdot \mathrm{M}^{0.53}\right)
$$

Where:

$\mathrm{n}=$ Grading efficiency, $\%$.

$\mathrm{S}=$ Grading speed, $\mathrm{rpm}(4-13 \mathrm{rpm}$ or $0.05-0.15 \mathrm{~m} / \mathrm{s})$.

$\mathrm{M}=$ Batch mass, $\mathrm{kg}$ (ranged between $5-20 \mathrm{~kg}$ ).

\section{3-4 Effect of grading speed, fruit batch and type of grading cylinder on fruit damage.}

Fig. 4 shows the effect of grading speed, fruit batch and type of grading cylinder (PVC cylinder and rubber coated cylinders) on fruit damage.

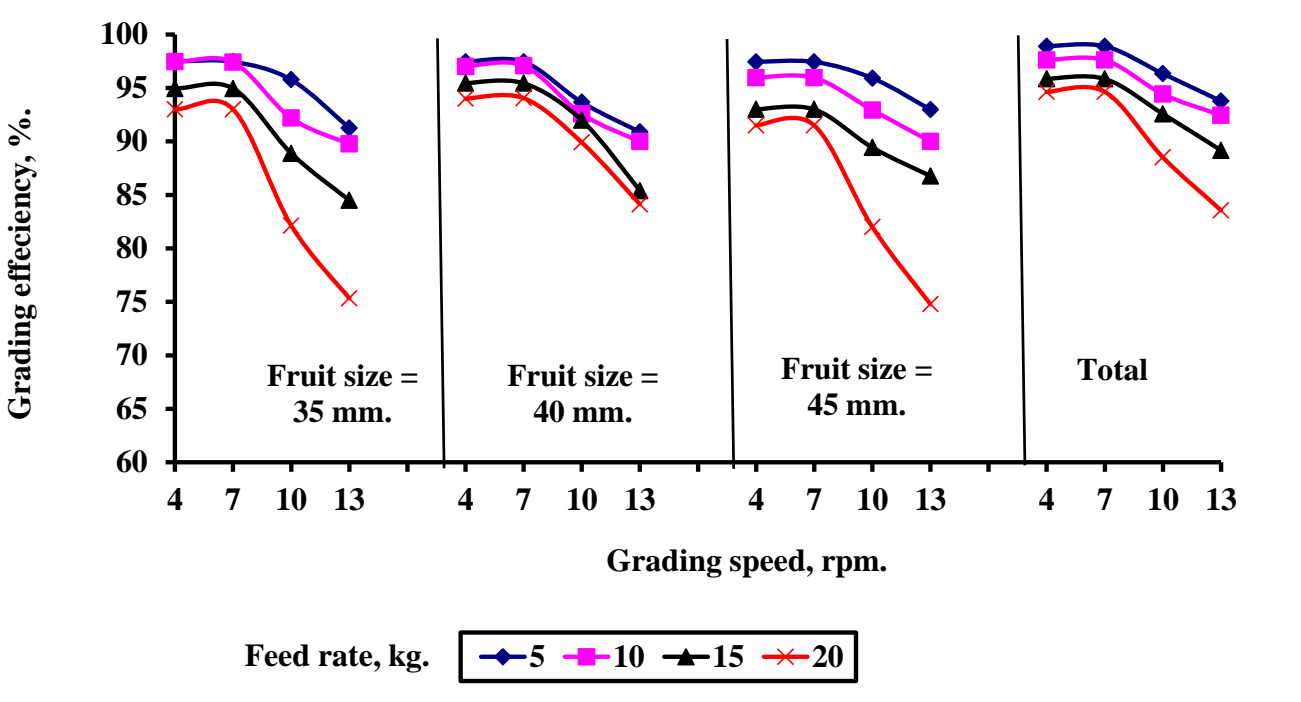

Fig. 3: Effect of grading speed, hole diameter of grading drums and fruit batch on grading efficiency. 
The fruit damage increased by increasing grading speed and decreased by increasing fruit batch for P.V.C. and rubber-coated cylinders. The maximum fruit damage of $4.14 \%$ was obtained with grading speed of 13 $\mathrm{rpm}(0.15 \mathrm{~m} / \mathrm{s})$ fruit batch of $5 \mathrm{~kg}$ and PVC cylinder. Meanwhile, the minimum fruit-damage of zero and $0.07 \%$ was obtained with grading speed of $4 \mathrm{rpm}(0.05 \mathrm{~m} / \mathrm{s})$ and fruit batch of $20 \mathrm{~kg}$ and rubber-coated cylinder.

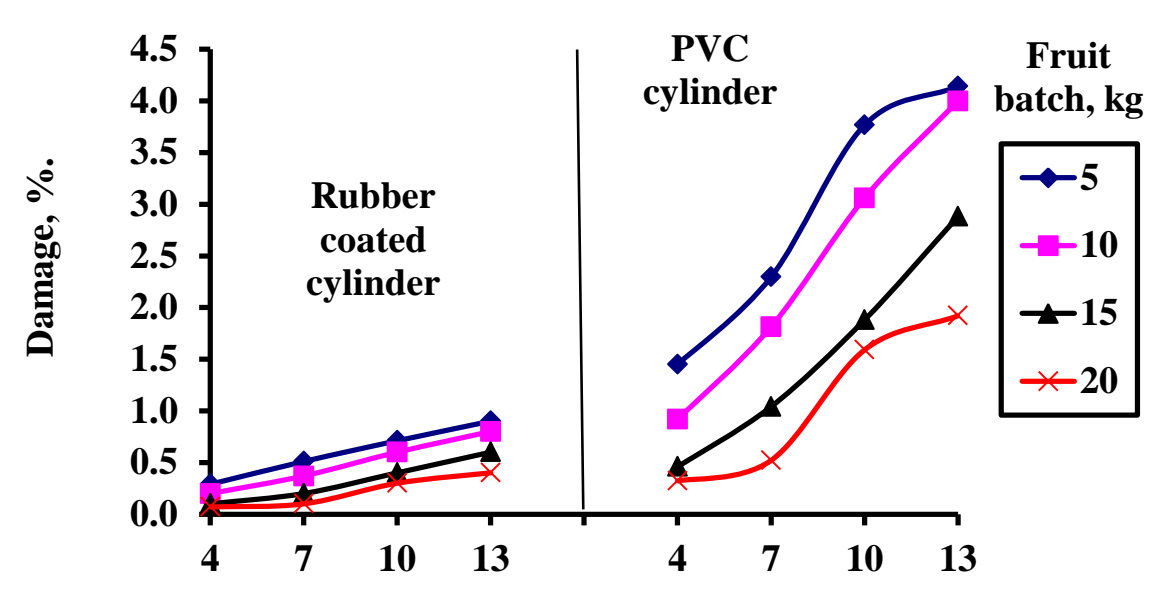

Grading speed, rpm.

Fig. 4: Effect of grading speed, fruit batch and type of grading cylinder (PVC and rubber-coated cylinders) on fruit damage.

The increasing of fruit damage by increasing grading speed is due to increasing impact force among fruits surface and grading drums. Meanwhile, the increasing of fruit damage of PVC cylinder is due to increasing friction among fruits surface comparing with rubber coated cylinder.

Factors affecting fruit damage were combined into prediction regressionequation under experiment and machine conditions as follows:

$\mathrm{Da}=\mathrm{C}_{1} \mathrm{~S}^{\mathrm{c} 2} / \mathrm{M}^{\mathrm{C} 3}$

Where:

$\mathrm{Da}=$ Fruit damage, $\%$.. 


$$
\begin{aligned}
& \mathrm{S}=\text { Grading speed, } \mathrm{rpm}(4-13 \mathrm{rpm} \text { or } 0.05-0.15 \mathrm{~m} / \mathrm{s}) . \\
& \mathrm{M}=\text { Batch mass, } \mathrm{kg} \text { (ranged between } 5-20 \mathrm{~kg} \text { ). }
\end{aligned}
$$

Table 3 shows constants of fruit-damage prediction equation.

Table 3: Constants of fruit-damage prediction equation.

\begin{tabular}{|c|c|c|c|c|}
\hline Grading drum & $\mathrm{C} 1$ & $\mathrm{C} 2$ & $\mathrm{C} 3$ & $\mathrm{R}^{2}$ \\
\hline PVC & 1.46 & 1.39 & 0.83 & 0.88 \\
\hline Rubber coated & 1.76 & 1.35 & 0.82 & 0.92 \\
\hline
\end{tabular}

\section{3-5 Effect of grading speed and fruit batch on grading productivity.}

Data in Fig.6 shows the effect of grading-speed and fruit batch on grading productivity by using rubber coated cylinder

By increasing grading-speed and fruit batch the grading productivity increased in general for peach fruits.

The maximum machine productivity of $1075.6 \mathrm{~kg} / \mathrm{h}$ was obtained with grading speed of $13 \mathrm{rpm}(0.15 \mathrm{~m} / \mathrm{s})$ and fruit batch of $20 \mathrm{~kg}$. Meanwhile, the minimum machine productivity of $295.9 \mathrm{~kg} / \mathrm{h}$ was obtained with grading speed of $4 \mathrm{rpm}(0.05 \mathrm{~m} / \mathrm{s})$, and fruit batch of $5 \mathrm{~kg}$.

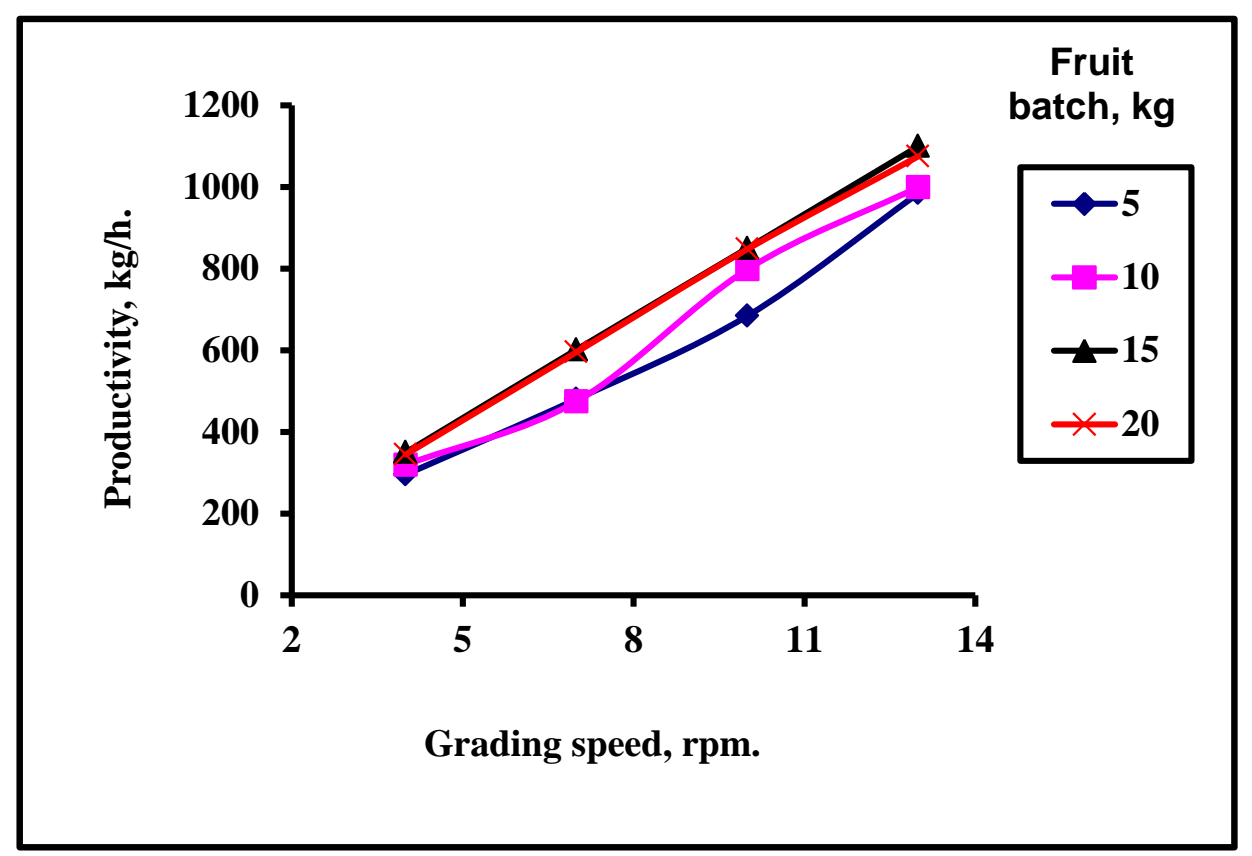

Fig. 5: Effect of grading speed and fruit batch on grading machine productivity. 
The increasing of grading-machine productivity by increasing grading speed and fruit batch is due to decreasing the time of grading and fruit mass respectively.

Factors affecting grading-machine productivity were combined into prediction regression-equation under experiment and machine conditions as follows:

$$
\mathrm{P}=2.15 \mathrm{~S}^{0.98} \cdot \mathrm{M}^{0.14}
$$

Where:

$\mathrm{P}=$ Grading efficiency, \%..

$\mathrm{S}=$ Grading speed, $\mathrm{rpm}(4-13 \mathrm{rpm}$ or $0.05-0.15 \mathrm{~m} / \mathrm{s})$.

$\mathrm{M}=$ Batch mass, $\mathrm{kg}$ (ranged between $5-20 \mathrm{~kg}$ ).

\section{3-6 Cost of using the designed grading-machine.}

The operation and production costs and rubber-coated cylinder) were 12.82 L.E./h and 26.98 L.E./ton at optimum conditions (grading speed of $7 \mathrm{rpm}$ or $0.08 \mathrm{~m} / \mathrm{s}$, fruit batch of $10 \mathrm{~kg}$ and rubber-coated cylinder.

\section{COUNCLUSION}

The optimum conditions of grading machine to be operated at the maximum efficiency are: grading speed of. $7 \mathrm{rpm} .(0.08 \mathrm{~m} / \mathrm{s})$, fruit batch of $10 \mathrm{~kg}$ and rubber-coated cylinder which gave grading efficiency of $97.6 \%$, fruit damage of $0.37 \%$, productivity of $475.1 \mathrm{~kg} / \mathrm{h}$, operation and production costs of 12.82 L.E./h and 26.98 L.E./ton respectively.

\section{REFERENCES}

Abd-Alla, H., S. M. Radwan, M., M. El-kholy and M. S. Radwan (2000). A weight grading machine for different fruits and vegetables. Misr J. Ag. Eng., 17(3):675-696.

Agric. Statistics Economic Affairs Sector, (2006). Data on citrus statistices, Oral com Prof. Dr. Latif, Sen, Res., Citrus Div., Hort.Res. Inst., A.R.C. 
Amin, E. E. A. A. (1994). Development of a grading machine for some horticulture farm crops. J.Agric. Sci. Mansoura Univ. 19(7) :31393149.

Awady, M. N., 1978, (updating 1998), Engineering of tractors and Agricultural machinery. TextBook., col. Ag., Ain-shams Univ., 5 th. Ed.,: 164-167. (In Arabic).

Buyanov, A. I. and B. A. Voronyuk (1985). Physical and mechanical properties of plant, Fertilizers and soils. Amerind Pub. Co., PVT., LTD., New Delhi, India. 753 P.

El-Raie, A. E., A. F. El-Sahrigi and M. M. Mousa (1998). Engineering factors affecting the development of grading machine for fruits. $6^{\text {th }}$ Conference of Misr Society of Ag. Eng., 21-22 Oct.: 79-90.

El-Raie, A. E., I. Yehia, M. Attallah, and K. S. Khalil (2012). Factors affecting the design a grading machine for lemon fruits, Misr J. Ag. Eng., 37(2): in Press.

Genidy, S. K. A. (2003). Manufacturing and performance evaluation of a locally machine grading of some vegetables and fruits. Ph. D. thesis Agric. Eng, Dept., Fac. Of Agric., Kafr-El Sheikh, Tanta Univ.

Matouk, A. M., A. M. El-Gengy, Y. M. El-Hadidi, E. A. Amin, and M. M. Abd El-Rahman (1999). Evaluation the effect of some mechanical parameters on handling characteristics of sphere-like crops. Misr J. Agric. Eng., 16(4):701-719.

Mohsenin, N. N. (1986). Physical properties of plant and animal materials. Gorden and Breach Sc. Pub., N. Y. 
Mostafa, H. M. S. (2003). Development an appropriate system for onion grading. Unpublished M. Sc. Thesis. Fac. Of Agric. Moshtohor. Zagazig Univ. Benha Braanch.

Mousa, M. M. (1998). Engineering factors affecting the development of grading machine for citrus, Ph. D., Fac. of Ag., Cairo U.: 126-255.

Patrick, C. (2002). Systems for pre-sprouting potatoes, crops technologist, green mount agricultural college, N. I., National Potatoes Conference, February, Burdens Distribution Ltd:1-2.

Xiaoyang, G, P. H. Heinemann and J. Irudayaraj (2003). Nondestructive apple bruise on line test and classification with Raman spectroscopy. Paper No:033025 an ASAE meeting presentation July 27-30.

\section{الملخص العزبي

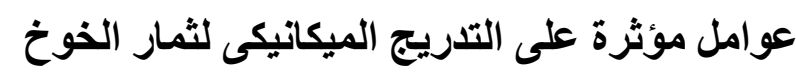 \\ أ.د. إبراهيم يحيى (')، د. جمال كمال عرفه (") ، د. أحمد عبد الرشيد(")}

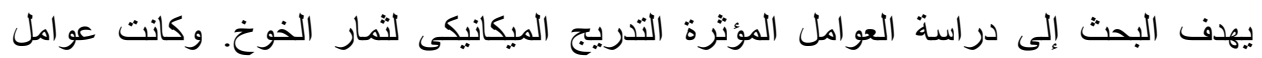

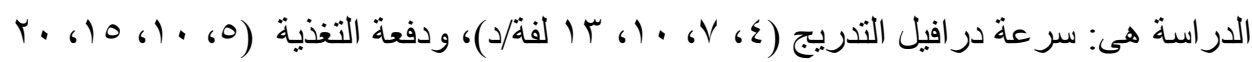

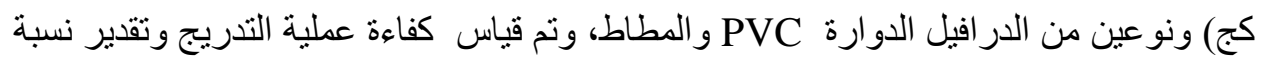

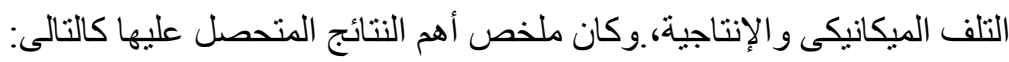
(1) تأثير سرعة أسطوانات التدريج وكمية الثمار على كفاءة التدريج.

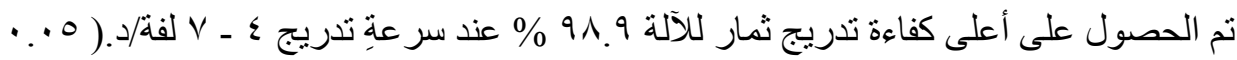

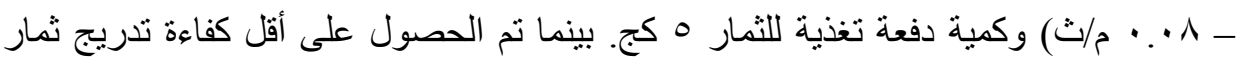

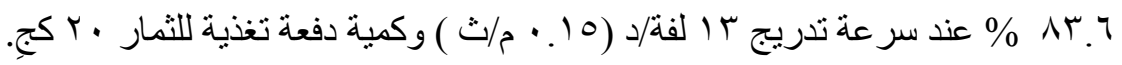

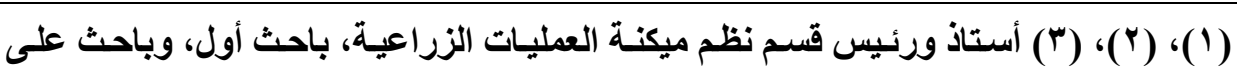

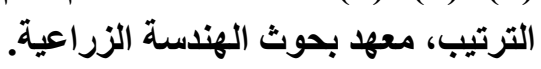


تأثير سرعة أسطوانات التدريج وكمية الثمار على التلف. (Y)

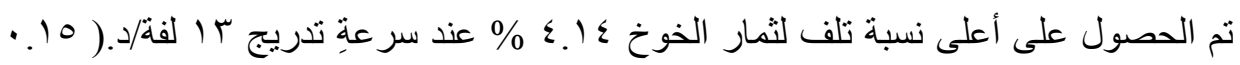

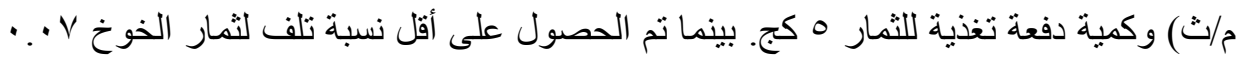

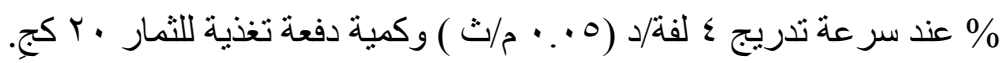

(ب) تأثير سرعة أسطوانات التدريج وكمية الثمار على الإنتاجية.

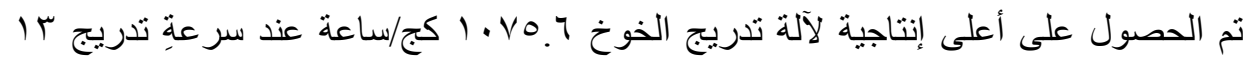

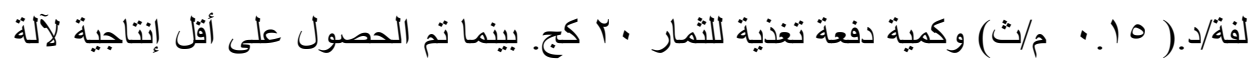

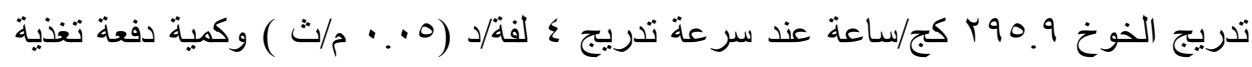
للثمار 0 كج.

\section{(ب) تكاليف استخدام الآلة.}

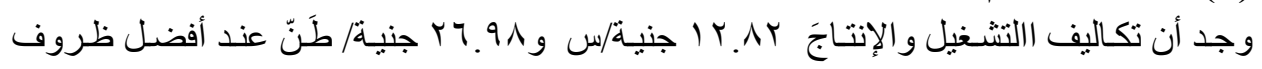

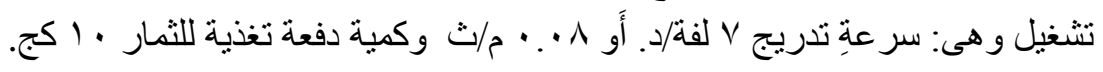

